\title{
DIREITO DE PROPRIEDADE: ANÁLISE DA POLÍTICA PÚBLICA FUNDIÁRIA NA CIDADE OLÍMPICA, EM SÃO LUÍS (MA)
}

\author{
Ângela Maria Pinheiro da Silva* \\ Cláudio Eduardo de Castro* \\ *Universidade Estadual do Maranhão, Programa de Pós-graduação em Geografia, Natureza e Dinâmica do \\ Espaço-PPGeo, São Luís, MA, Brasil.
}

\begin{abstract}
Resumo
São Luís, assim como outras cidades do país, passou por intenso processo de urbanização entre 1950 e 1980, caracterizado pela forma acelerada e sem planejamento com que ocorreu, resultando na ocupação espraiada e dispersa em áreas periféricas, causando uma série de problemas sociais, ambientais, jurídicos e urbanísticos. Com o elevado número de habitações irregulares e a precariedade habitacional nos espaços urbanos, foi regulamentado no Brasil o direito à moradia digna e às políticas de regularização fundiária, que se consolidaram como políticas públicas a partir de 1980. A abordagem desta pesquisa consiste na análise relativa ao direito de propriedade, baseada na ocupação da Cidade Olímpica, na capital maranhense. O enfoque recai na emissão de títulos de propriedade privada no referido bairro, por meio do Programa de Regularização Fundiária Urbana em São Luís, com a ressalva de que a regularização fundiária não se limita à transferência de títulos fundiários. Para que ocorra de forma plena, esta deve estar articulada à regularização urbanística.

Palavras-chave

Regularização Fundiária; Informalidade; Cidade Olímpica; Direito de Propriedade; Política Pública.
\end{abstract}




\title{
ARTICLES
}

PLANNING AND PUBLIC POLICY

\section{PROPERTY RIGHTS: ANALYSIS OF THE PUBLIC LAND POLICY IN THE CIDADE OLÍMPICA, IN SÃO LUÍS (MA)}

\author{
Ângela Maria Pinheiro da Silva* \\ Cláudio Eduardo de Castro* \\ *Universidade Estadual do Maranhão, Programa de Pós-graduação em Geografia, Natureza e Dinâmica do \\ Espaço-PPGeo, São Luís, MA, Brazil.
}

\begin{abstract}
São Luís, like other cities in Brazil, underwent an intense process of urbanization between the 1950s and 1980s, characterized by an accelerated and unplanned form, resulting in sprawling and dispersed occupation in peripheral areas, causing a series of social, environmental, legal and urbanistic problems. With the high number of irregular dwellings and precarious housing in urban spaces, Brazil has regulated the right to decent housing and land regularization policies, which have been consolidated as public policies since the 1980s. The approach of this research consists in the analysis of Property Law, based on the occupation of Cidade Olimpica, focusing on the issuance of private property titles in the neighborhood, through the Urban Land Regularization Program in São Luís. However, it should be noted that land regularization is not limited to the transfer of land titles. In order for this to occur in full, it must be articulated to urban regularization.

Keywords

Landholding Regularization; Informality; Cidade Olímpica; Property Law; Public Policy.
\end{abstract}




\title{
DIREITO DE PROPRIEDADE: ANÁLISE DA POLÍTICA PÚBLICA FUNDIÁRIA NA CIDADE OLÍMPICA, EM SÃO LUÍS (MA)
}

\author{
Ângela Maria Pinheiro da Silva \\ Cláudio Eduardo de Castro
}

Introdução

A humanidade levou milhares de anos para atingir uma população de um bilhão de indivíduos. Para alcançar o segundo bilhão, foram necessários pouco mais de cem anos. Contudo, em apenas trinta anos, chegou-se ao terceiro bilhão, isso nos anos 1960. Atualmente, a população mundial ultrapassa 7 bilhões de pessoas, das quais 55\% (ONU, 2019a) vivem em áreas urbanas. Tamanha população exerce enorme pressão sobre as cidades, que cresceram em uma velocidade avassaladora, o que as levou a enfrentar novos desafios, principalmente abrigar mais gente em um espaço reduzido. E, nesse processo, milhões de pessoas se mudaram para assentamentos não planejados. Por isso, o espaço da cidade foi sendo ocupado, de maneira regular ou não, formal ou informalmente.

Em São Luís, entre as décadas de 1950 e 1980, houve aumento do contingente populacional com taxa de crescimento de $284 \%$. A população ludovicense saltou de 119 mil habitantes em 1950 para 460 mil em 1980 (SANTO, 2006), ou seja: em trinta anos, a população da cidade quase triplicou.

De acordo com Ribeiro Júnior (2001), na década de 1960 a capital do Maranhão atingiu um quadro desolador: muita população e poucos serviços urbanos, empregos e riqueza. E não só a população aumentou como também houve crescimento do território ocupado, dez vezes maior que o construído desde 1612, mediante a transferência de terras federais para o município. Naquele período, as transferências de terras federais para o município anexaram, aos 4.356 hectares das sesmarias da região central da cidade, um total de 47.772 hectares das áreas do Rio Anil, 
Itaqui-Bacanga e Tibiri-Pedrinhas (BURNETT, 2011). Até essa década, o contexto socioespacial de São Luís se caracterizava por ser compacto e contínuo, mas a partir da década de 1970 sua urbanização se tornou espraiada e fragmentada.

Dos 60 milhões de domicílios urbanos, 50\% dos imóveis não têm escritura (BRASIL, 2019). A informalidade e a irregularidade dos imóveis se fazem presentes nas diferentes classes sociais, de condomínios de luxo a favelas. Dentre as causas, enquadram-se ocupações e loteamentos que foram criados e vendidos ilegalmente.

Para Harvey (1982), o processo de criação do espaço é cheio de contradições e tensões, grande parte das quais relacionadas a conflitos de terra, tanto no meio rural como no urbano. Os problemas ocasionados no país pela ausência de regularidade fundiária são enormes, uma vez que permitem a sonegação fiscal; assim, então, municípios, estados e União deixam de arrecadar bilhões em tributos como o Imposto Predial e Territorial Urbano (IPTU), o Imposto sobre a Transmissão de Bens Imóveis (ITBI) e o Imposto de Renda (IR), que poderiam sem utilizados em investimentos em infraestrutura das cidades.

Segundo Soto (2001, p. 63 e 254), "a propriedade formal é mais do que mera posse, ela nos força a pensar a casa como um conceito econômico e social”, além da visão de mero abrigo. Esse fato nos leva a refletir ainda mais sobre o conceito da moradia como um lar, particularizada e impregnada de sentido e história, "uma espécie de proteção, não apenas material, contra as intempéries naturais e urbanas, mas também psíquica e emocional" (BOSCO, 2017, p. 4). E as perdas com a dificuldade de regularização fundiária vão além, pois, sem o documento legalizado, os proprietários não conseguem financiamentos por não poderem oferecer o imóvel como garantia.

Dados da pesquisa Perfil municipal (IBGE, 2002) revelam a presença de assentamentos irregulares em quase $100 \%$ das cidades brasileiras com mais de 500 mil habitantes, como também atestam Rolnik et al. (2007). Somente na cidade de São Luís existem atualmente 96 aglomerados subnormais (G1-MA, 2020), dentre os quais se inclui Cidade Olímpica, objeto deste estudo, enquadrado nessa categoria e oriundo de um processo de ocupação iniciado em 1996. Esse bairro acabou por se constituir em uma das maiores ocupações da América Latina (FIEMA, 2015) e um dos conglomerados mais populosos e violentos da Grande São Luís (MARANHÃO, 2017), o qual se tornou um símbolo de luta pela moradia com relevância local e nacional, principalmente pelo alto poder de organização de sua população.

Este artigo analisa a política pública urbana de regularização fundiária executada na Cidade Olímpica, levando em consideração os processos de titulação definitiva dos imóveis, contextualizando o arcabouço legal federal, estadual e/ou 
municipal que subsidiou a emissão dos títulos de propriedade para os imóveis no bairro, de modo a identificar o número de imóveis titulados e não titulados.

Na averiguação, durante a implementação do Programa de Regularização Fundiária no bairro, analisou-se o processo histórico de ocupação da localidade, utilizando-se como fonte jornais da época e entrevistas com lideranças e pessoas da comunidade que participaram diretamente da ocupação. No ensejo de discorrer sobre o processo de regularização fundiária, foi feito o levantamento do processo jurídico de compra da área pelo estado do Maranhão, resultante de consultas aos cartórios de São Luís e de São José de Ribamar, envolvidos nessa ação.

Por meio de banco de dados fornecido pela Secretaria de Estado das Cidades e Desenvolvimento Urbano do Maranhão (Secid) e da elaboração de mapa da área, identificaram-se as propriedades que tiveram os títulos emitidos e os terrenos identificados como vazios. O mapa foi elaborado em ArcGis 10.2, e o georrefenciamento foi feito com base nos memoriais descritivos, contendo as coordenadas geográficas, elaborado e disponibilizado pelo Sindicato das Indústrias da Construção Civil do Maranhão (Sinduscon-MA).

Foram aplicados questionários fechados a pessoas da comunidade que receberam os títulos de propriedade. Houve ainda mais dois momentos de aplicação de questionários, durante a realização das entrevistas semiestruturadas na sede da associação com moradoras da Cidade Olímpica que participaram do ato de ocupação e que são lideranças na localidade e com outros que são referência na comunidade. Os questionários estão pulverizados dentro dos três blocos: foram 21 pessoas do Bloco A, 25 do Bloco B e 32 do Bloco C. Com as entrevistas e os questionários, pôde-se analisar a percepção dos moradores quanto à abrangência-efetividade-resultados do Programa de Regularização Fundiária implantado ali.

Também são expostos o histórico de ocupação do bairro, os três processos de regularização desenvolvidos na localidade, em 2003, 2013 e 2015, assim como os marcos jurídicos e os instrumentos utilizados para regularizar e titular os lotes da Cidade Olímpica.

\section{Informalidade e irregularidade na urbanização}

A questão fundiária está no centro da discussão sobre o conceito de informalidade e irregularidade, fatores que exercem forte influência na compreensão da urbanização das cidades, em especial nas da América Latina a partir da década de 1970. Neste tópico busca-se apresentar de que forma a informalidade afeta a produção do espaço e qual é a relação do processo de urbanização brasileira para a formação dos aglomerados subnormais e, consequentemente, da Cidade Olímpica. 
O aumento da população urbana ocorre em âmbito mundial. Esse crescimento populacional transformou as cidades num verdadeiro caos, com insuficiência de espaço e de moradia e carência de infraestrutura básica. Num retrospecto sobre 0 crescimento da população urbana mundial, colhe-se: (a) 1800 - de $2 \%$ a $3 \%$ de toda a população mundial vivendo em cidades; (b) 1900 - população urbana próxima dos 15\%; (c) 1950 - população urbana de 29,6\% (ONU, 2019b).

A partir de 2007, segundo dados da Organização das Nações Unidas (ONU, 2019b), a população urbana global tornou-se predominante. Em um período de quarenta anos, ela passou de $38 \%$ para $55 \%$ do total; quase 900 milhões das pessoas que vivem em áreas urbanas estão concentradas em favelas pulverizadas por todo o mundo, com restrição aos serviços básicos de infraestrutura. Davis (2006) aponta que, em 1950, havia 86 cidades com mais de um milhão de habitantes no mundo e, em 2015, já eram 550. A América Latina é a região mais urbanizada atualmente, uma vez que $82 \%$ de sua população reside em áreas urbanas (FAJERSZTAJN; VERAS; SALDIVA, 2016), embora até um terço dessa população esteja na informalidade do tecido urbano das grandes cidades latino-americanas (FERNANDES, 2011).

No início dos anos 1960, com a crise habitacional muito forte no Brasil, estava claro que o Estado não daria conta das necessidades habitacionais dos brasileiros, num momento de grande migração para as cidades. Muitos desses migrantes, trabalhadores de baixa renda, tiveram acesso à moradia apenas por meios informais, principalmente nas favelas, em invasões/ocupações e em loteamentos periféricos irregulares, por não poderem arcar com os custos do solo urbano, uma vez que, geralmente, "os lugares onde é melhor morar [...] são mais reservados aos que podem consumi-los” (SANTOS, 2009, p. 10).

De acordo com Cardoso (2003), a irregularidade se apresenta por meio: (a) da irregularidade quanto à propriedade da terra ou do imóvel, como resultado de processos de ocupação; (b) da irregularidade parcial ou da inadequação da documentação da propriedade (registro/título/escritura) - não havendo, neste caso, processo de ocupação; (c) da irregularidade na produção dos loteamentos, nos quais não há licenciamento na prefeitura e existe desacordo quanto à legislação vigente no tocante ao dimensionamento dos lotes, reserva de área institucional etc.; (d) da irregularidade na edificação, que também não conta com licenciamento na prefeitura; (e) por fim, há ainda os casos em que a irregularidade se estende às questões fundiárias e edílicas.

Portanto, a informalidade está relacionada à ausência de formalidade, referindo-se àquilo que está em desconformidade com a legislação vigente. E a irregularidade urbana, por sua vez, se associa àquilo em que não há regulação, ao que se 
encontra em desacordo com os regulamentos. Ambas apresentam a mesma definição, no sentido de indicar que algo está fora da ordenação jurídica e urbanista vigente, e representam a dualidade da cidade formal em contraposição à cidade informal, recorrente nas cidades brasileiras, em que a informalidade "ocupa uma área seguramente maior que a área ocupada pela cidade 'legal”” (ALFONSIN, 2007, p. 72).

O Estado exerce papel relevante na produção da cidade informal e, em muitos casos, é um dos principais atores no desenvolvimento e na consolidação dessas áreas, tendo em vista que essa informalidade não está fora de seu escopo e ele não está ausente desses espaços (GONÇALVES; BAUTÈS; MANEIRO, 2018).

Dados da Pesquisa Nacional por Amostra de Domicílios (PNAD) (IBGE, 2016) apontam que a maior parte da população brasileira (84,72\%) vive em áreas urbanas: 41,2\% está em assentamentos precários, informais ou em domicílios inadequados; no Maranhão, 77,1\% da população vive em alguma condição de irregularidade e/ou informalidade (IBGE, 2010). São Luís é a quarta capital brasileira com maior percentual de pessoas vivendo em aglomerados subnormais, ou seja: ocupações irregulares em terrenos públicos ou privados com padrão urbanístico irregular e carência de serviços públicos essenciais (IBGE, 2020).

Em 2010, o índice de domicílios caracterizados como subnormais em São Luís era de 61.845 (IBGE, 2010), distribuídos em 39 aglomerados subnormais. Esse número chegou a 101.030, em 2020, segundo o ranking publicado pelo IBGE (2020) para o enfrentamento da Covid-19. No ano de 2010, o bairro Cidade Olímpica não era configurado como aglomerado subnormal, de acordo com a classificação do Censo, apesar de ser uma ocupação irregular, cujos moradores não possuíam título de propriedade dos imóveis em que moravam, e, principalmente, em razão da carência no fornecimento de serviços públicos essenciais, conforme apontado no Relatório de análise de cenários de São Luís (SÃO LUís, 2013), em que se menciona que a Cidade Olímpica tem acesso extremamente precário ao saneamento, abaixo de $1 \%$. Na atualidade, existem 96 aglomerados subnormais, representando 32,42\% de todas as habitações do município.

Verifica-se, com base na Figura 1, como estão pulverizados no espaço da cidade de São Luís os assentamentos informais. "Não se trata de formas de morar simplesmente, mas de formas de morar na cidade” (SANTOS, 2009, p. 9), causados por um processo histórico de irregularidade jurídico-urbanista, “com a existência de formas de vida e de desenvolvimento espacial modernos que exigem corolários, como favelas e outras formas de ‘submoradia”' (SANTOS, 2009, p. 10). 


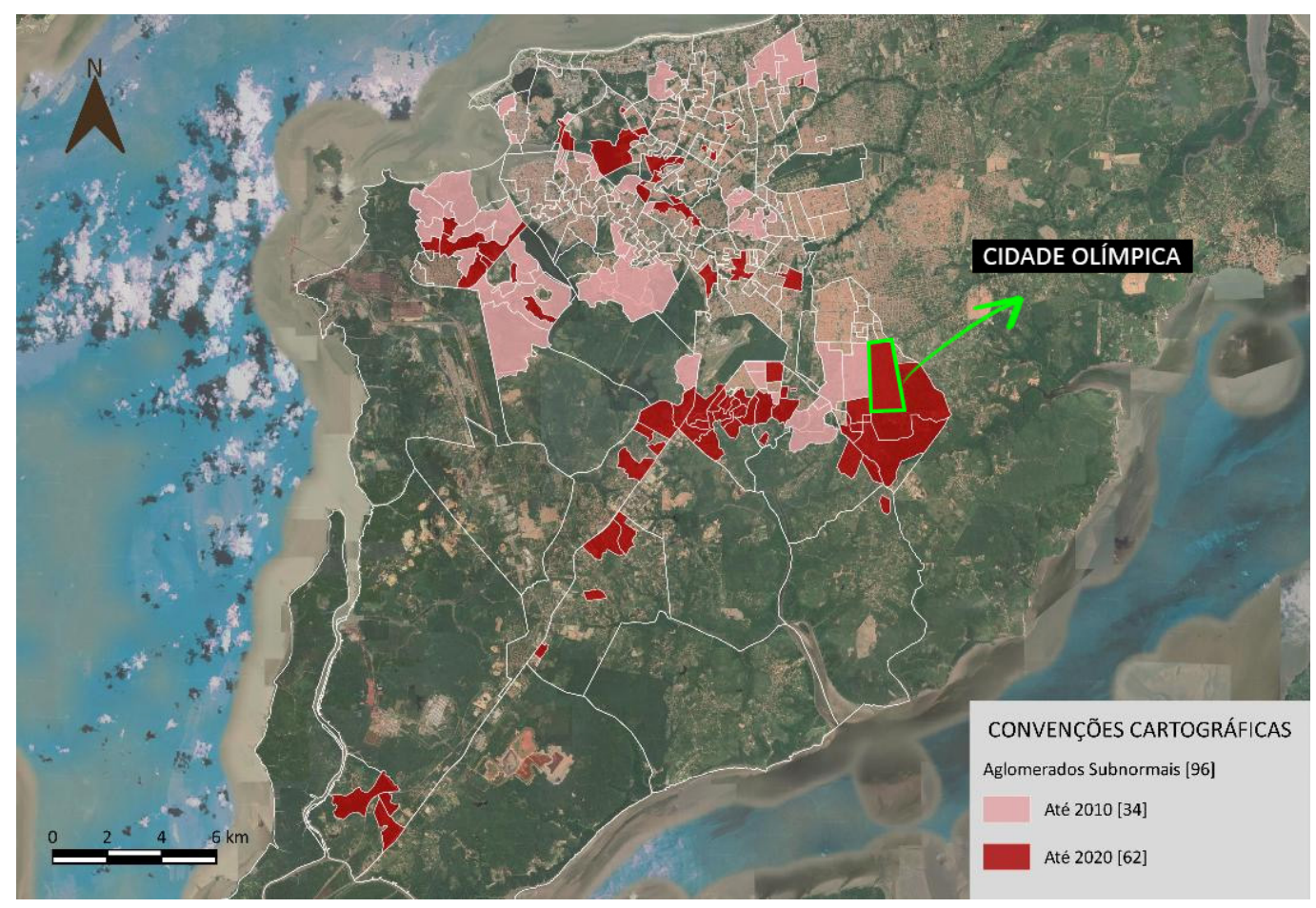

Figura 1. Mapa dos aglomerados subnormais em São Luís (2020)

Fonte: Elaborado pela autora, com base em informações do IBGE (2020).

\section{Regularização de assentamentos informais}

O processo de urbanização da América Latina e no Brasil especificamente tem se destacado por sua intensidade: presenciou-se um crescimento acentuado no número de cidades, no tamanho delas e na proporção de pessoas vivendo nelas. Em consequência, a informalidade cresceu mais rápido que a capacidade de o poder público urbanizar e regularizar. Tendo em vista esse cenário, a busca pela reforma urbana no país teve início na década de 1960. Entretanto, apenas a partir de 1980 é que foram realizadas as primeiras intervenções municipais em áreas informais e impostos os primeiros entraves nos quesitos de irregularidade e ilegalidade, propriedade privada e função social da propriedade.

Segundo Gonçalves (2009, p. 237), "as políticas de regularização de favelas consolidaram-se no Brasil, como política urbana, a partir do início da década de 1980". Efetivamente, entre 1980 e o início de 1990, houve um primeiro ciclo da reforma urbana. Para Arantes (2013, p. 1), "foi quando se reconheceu, nas políticas públicas e na academia, a 'cidade oculta', fora dos planos e leis, autoconstruída pelos trabalhadores”. Foi nesse momento que as prioridades se inverteram. A política de remoção forçada de favelas deu espaço a um urbanismo democrático-popular com a proposta de urbanizar as favelas, com a aplicação de um conjunto de 
práticas que se desenvolveram em importantes cidades brasileiras, sob a gestão de governos locais (CARDOSO, 2007).

De acordo com Arantes (2013), a propriedade privada não foi questionada e combatida no diálogo e na proposta para o programa da reforma urbana. Segundo esse autor, "ampliar o acesso à moradia parecia ser o mesmo que ampliar o acesso à propriedade privada" (2013, p. 1), posto que, entre os próprios movimentos sociais, grandes protagonistas na busca pela reforma urbana, havia uma confusão/ sobreposição entre direito à moradia e direito à propriedade, apresentados como sinônimos. Com foco no Quadro 1, é possível verificar algumas diferenças entre os dois termos.

\begin{tabular}{|l|l|}
\hline \multicolumn{1}{|c|}{ Direito à moradia } & \multicolumn{1}{|c|}{ Direito à propriedade } \\
\hline $\begin{array}{l}\text { 1. Direito prestacional. Identifica-se com os direitos } \\
\text { de segunda dimensão em que se colocam os } \\
\text { direitos sociais. Exigem do Estado uma atuação } \\
\text { ativa na realização da justiça social. }\end{array}$ & $\begin{array}{l}\text { 1. Direito defensivo. Identifica-se com os direitos de } \\
\text { primeira dimensão, em que se colocam os direitos } \\
\text { civis e políticos. Limitam a ingerência estatal. }\end{array}$ \\
\hline $\begin{array}{l}\text { 2. Positivado no artigo } 6^{\circ} \text { da Constituição Federal. } \\
\text { São direitos sociais a educação, a saúde, a } \\
\text { alimentação, o trabalho, a moradia. }\end{array}$ & $\begin{array}{l}\text { 2. Presente no artigo } 5^{\circ} \text { da Constituição Federal de } \\
\text { 1988, inviolabilidade do direito à vida, à liberdade, } \\
\text { à igualdade, à segurança e à propriedade, e nos } \\
\text { incisos XXII e XXIII, em que se garantem o direito de } \\
\text { propriedade e o atendimento, pela propriedade, à } \\
\text { sua função social, respectivamente. }\end{array}$ \\
\hline $\begin{array}{l}\text { 3. Direito presente na Declaração Universal dos } \\
\text { Direitos Humanos, em seu artigo 25, parágrafo 10 }\end{array}$ & $\begin{array}{l}\text { 3. Positivado no conteúdo do artigo 1.228 do Código } \\
\text { Civil. }\end{array}$ \\
\hline $\begin{array}{l}\text { 4. O direito à moradia representa uma necessidade } \\
\text { intrínseca e vital ao ser humano. }\end{array}$ & $\begin{array}{l}\text { 4. O direito à propriedade privada é um benefício, } \\
\text { uma conquista não vital e, muitas vezes, } \\
\text { dispensável. }\end{array}$ \\
\hline
\end{tabular}

Quadro 1. Direito à moradia versus direito à propriedade

Fonte: Facchini (2014), Mateus (2005) e Padilha (2017).

Na ânsia de garantir às populações de mais baixa renda a permanência nos locais já ocupados por meio de titulação e, por conseguinte, a segurança da posse, "aceitou-se a regularização fundiária sem a efetivação da infraestrutura e de moradia adequada" (ARANTES, 2013, p. 1). Em decorrência disso, de acordo com Gonçalves (2009, p. 237), o balanço dos programas de legalização do solo é, ao menos por enquanto, extremamente negativo, pois as iniciativas se perdem na burocracia brasileira, "revelando a incapacidade da estrutura jurídica atual do país de integrar à formalidade uma grande parcela da população urbana” (GONÇALVES, 2009, p. 237).

Para Cardoso (2007, p. 229), “as experiências de urbanização e regularização de assentamentos precários disseminam-se ao longo da década de 90 em quase 
todas as grandes cidades do país”, seguindo os modelos de intervenção: (a) urbanização, a intervenção que não modifica a estrutura do assentamento; (b) reurbanização, que refaz completamente a estrutura do assentamento, com novo parcelamento e o reassentamento das famílias na mesma área; (c) remoção, que implica a retirada da população e seu reassentamento em outra área a depender de inúmeros fatores (CARDOSO, 2007, p. 229). "As experiências pioneiras do Recife e Belo Horizonte, nos anos de 1980, inovaram ao demarcar as Zonas Especiais de Interesse Social (ZEIS) criando mecanismos para a sua regularização” (ROLNIK, 2015, p. 319).

Projetos como Profavela (Belo Horizonte), PREZEIS (Recife), Favela-Bairro (Rio de Janeiro) e outros desenvolvidos no $\mathrm{ABC}$ paulista trouxeram à discussão os conceitos de propriedade privada e função social da propriedade, principalmente pelo aumento nas ocupações no Brasil e nos inúmeros conflitos fundiários, muitas vezes violentos, com despejos e remoções forçadas, conforme veremos a seguir, na ocupação objeto deste estudo.

\section{O processo histórico de ocupação da Cidade Olímpica}

O bairro Cidade Olímpica, objeto desta pesquisa, é oriundo de um processo de ocupação irregular iniciado no ano de 1996. A comunidade constitui-se em uma das maiores ocupações da América Latina (FIEMA, 2015) e um dos conglomerados mais populosos e violentos da Grande São Luís (MARANHÃO, 2017). Tornou-se um símbolo de luta pela moradia com relevância local e nacional, principalmente pelo alto poder de organização da população.

De acordo com Maricato (1999, p. 1), "a invasão de terras urbanas no Brasil é parte intrínseca do processo de urbanização [...] ela é estrutural e institucionalizada tanto pelo mercado imobiliário quanto pela ausência de políticas sociais”.

De 1971 a 1999, foram construídos na ilha do Maranhão, onde se encontram São Luís e outros três municípios, 55 conjuntos habitacionais, entre os quais Angelim, Vinhais, Maiobão, Cidade Operária, São Raimundo, Jardim América I e II, Ipase, Cohama, Cohajap, Cohatrac, Cohapam, Cohab-Anil I, II, III e IV, compondo uma mancha urbana descontínua na cidade (LOPES, 2008, p. 38), com vazios urbanos nas proximidades desses novos bairros que foram ocupados ao longo do tempo.

A Cidade Olímpica está localizada no município de São Luís, a leste da capital maranhense. Limita-se ao norte com o Conjunto Habitacional Geniparana, ao sul com o Sítio Riod, a oeste com a Vila Janaína e a leste com o Santana, ponto em que é limítrofe com o município de São José de Ribamar (Figura 2). 


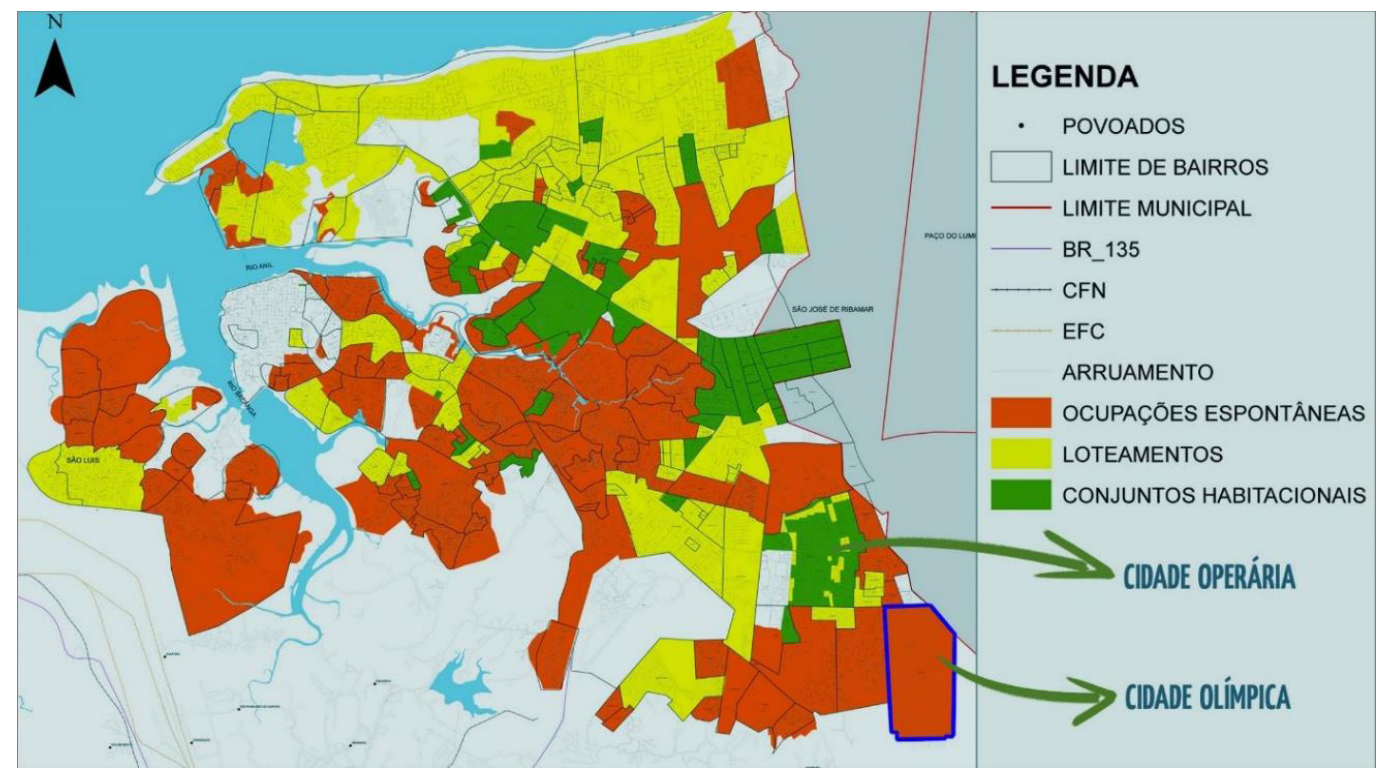

Figura 2. Conjuntos habitacionais e ocupações surgidas no entorno

Nota: *As siglas CFN e EFC representam, respectivamente, Companhia Ferroviária do Nordeste e Estrada de Ferro Carajás.

Fonte: Instituto da Cidade, Pesquisa e Planejamento Urbano e Rural (Incid) (2010).

A primeira ocupação, no terreno que hoje se configura como o bairro, ocorreu no dia 23 de julho de 1996 (SOARES, 2008), momento em que quase três mil famílias ocuparam uma área de 1.437 hectares, de propriedade da empresa Sociedade Butano Ltda., pertencente ao Grupo Edson Queiroz. Essas famílias foram organizadas por um candidato ao cargo de vereador que cobrava uma taxa de R 2,00 (dois reais) por lote. Segundo ele, esse valor seria utilizado para cadastrar os terrenos para o assentamento das famílias. Como em tantas outras localidades, o processo de ocupação teve motivação político-eleitoral. Conforme Cardoso (2016, p. 34), “o apoio de políticos locais à ocupação ilegal de áreas urbanas foi determinante na manutenção de vínculos de clientela entre estes políticos e as populações faveladas”. Porém, em virtude de o processo de desocupação da área da Cidade Olímpica ter sido violento, o referido político não prosseguiu com seu apoio à ocupação.

No início do mês de setembro de 1996, o juiz da comarca de São José de Ribamar expediu uma liminar para reintegrar a posse ao proprietário, a empresa Butano Ltda. Os barracos de madeira e taipa, aproximadamente 15 mil, foram então demolidos.

Em 4 de novembro daquele mesmo ano, foi organizada, pelos recém-criados movimentos de luta pela moradia em São Luís, a Marcha pela Reforma Urbana, com o objetivo de chamar a atenção para o problema da moradia na cidade. De acordo com Rabêlo (2012, p. 77), “os atos públicos continuaram na cidade por um 
longo tempo; a população, não somente da Cidade Olímpica, saía às ruas para reivindicar seus direitos”. Os ocupantes da localidade, por sua vez, formaram a Comissão dos Sem-Teto.

Em 29 de dezembro de 1996, em assembleia, a população decidiu ocupar a área novamente (Figura 3). Houve confronto armado com os vigilantes. Note-se que essa nova ocupação contou com aproximadamente 2.500 pessoas (RABÊLO, 2012) e com o apoio do Fórum Maranhense da Moradia, do Movimento Nacional de Luta pela Moradia, do Sindicato dos Servidores Públicos (SINDSEP), da Central Única do Trabalhador (CUT), da Cáritas Brasileira e da Igreja João Calábria.

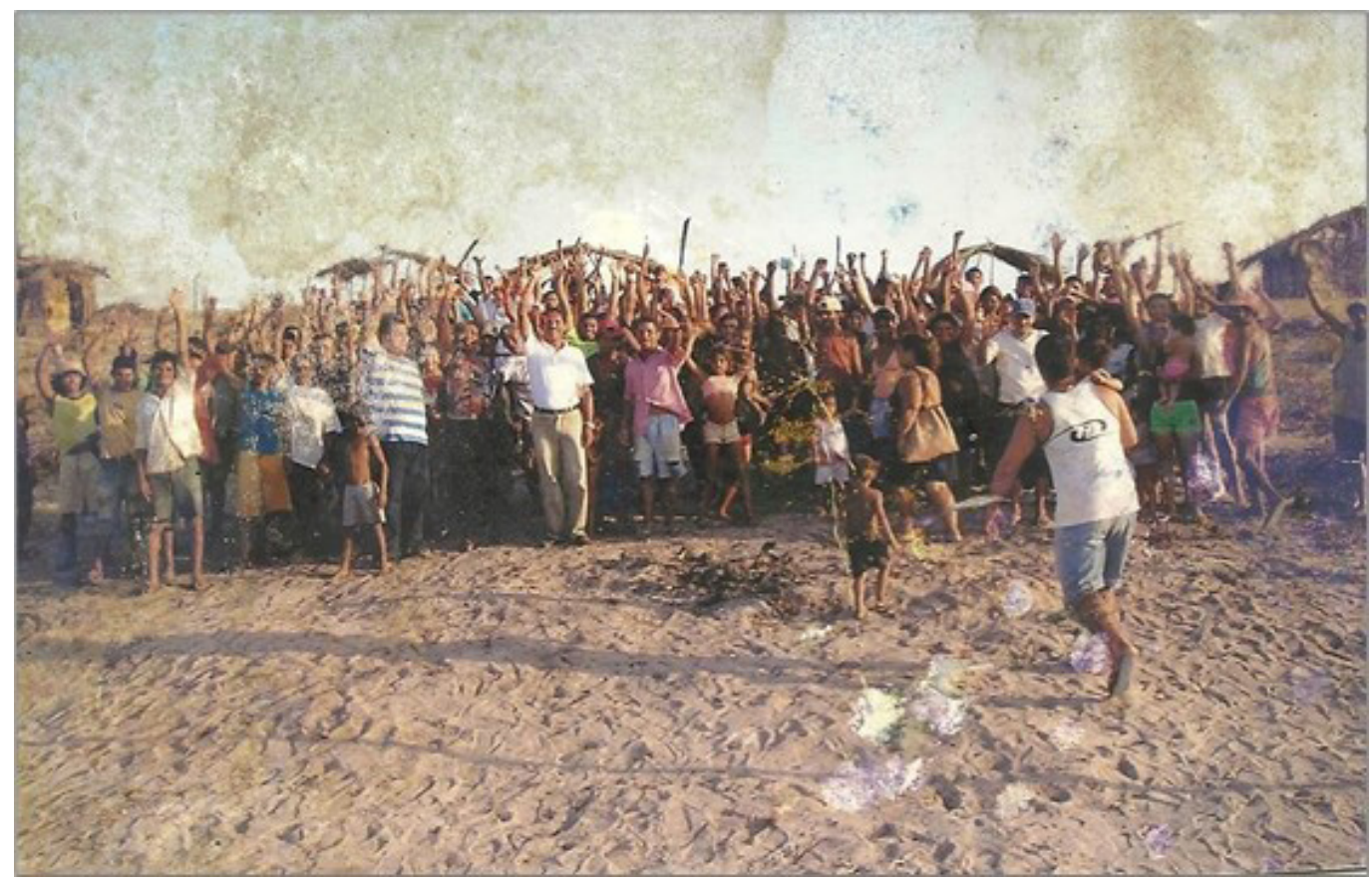

Figura 3. Reocupação da Cidade Olímpica

Fonte: Associação dos Moradores da Cidade Olímpica (Amcol) (2019).

Aos 22 de janeiro de 1997, a comarca de São José de Ribamar expediu a segunda liminar para reintegração de posse. Apesar do violento confronto com a polícia, houve resistência dos ocupantes, que não se retiraram da área. Soares (2008) acredita que, nesse momento, já havia mais de seis mil pessoas cadastradas e com lotes no local, as quais viveram ali, efetivamente, de dezembro de 1996 a janeiro de 1997.

Em virtude da recusa dos ocupantes de se retirarem do terreno, e a fim de evitar maiores conflitos, foi acordado em 23 de janeiro de 1997 que a população da Cidade Olímpica se limitaria a permanecer em uma área de um hectare, por vinte dias, prorrogáveis por mais dez (SOARES, 2008). O governo do estado do Maranhão se comprometeu a resolver nesse prazo a situação de litígio da localidade, adquirindo a propriedade da família Queiroz. 
Em 23 de março de 1997, a população foi autorizada a ocupar os lotes, enquanto tramitava o processo de compra e venda da área. O loteamento foi feito pela própria Comissão dos Sem-Teto. A ocupação da Cidade Olímpica se diferencia das demais porque apresenta ruas bem definidas, com traçado ortogonal e características de conjunto residencial, com lotes que têm a mesma medida (10 m x 20 m).

Dessa forma, é possível afirmar que o bairro seguiu um planejamento. A localidade foi distribuída em três blocos, A, B e C, cada um dividido em quadras, totalizando 419, e cada quadra subdivida em 22 lotes, num total de 12 mil lotes (SOARES, 2008). É composta de 8 avenidas, 22 ruas e 20 travessas. Também foram destinadas quadras para áreas institucionais. Porém, ao longo dos anos, o traçado de algumas quadras foi alterado, além de os lotes institucionais e as margens do córrego Santo Antônio terem sido ocupados.

Efetivamente, em 23 de janeiro de 1998 uma área de 270 hectares, pertencente à gleba de 1.437 hectares de propriedade da Sociedade Butano Ltda., denominada Gleba São Braz e Macacos, situada em São José de Ribamar, foi adquirida pelo governo do estado do Maranhão, em nome da Cohab-MA, pelo valor de $\mathrm{R} \$ 500.000,00$ (quinhentos mil reais) para o assentamento das famílias da Cidade Olímpica, conforme se vê na Figura 4.

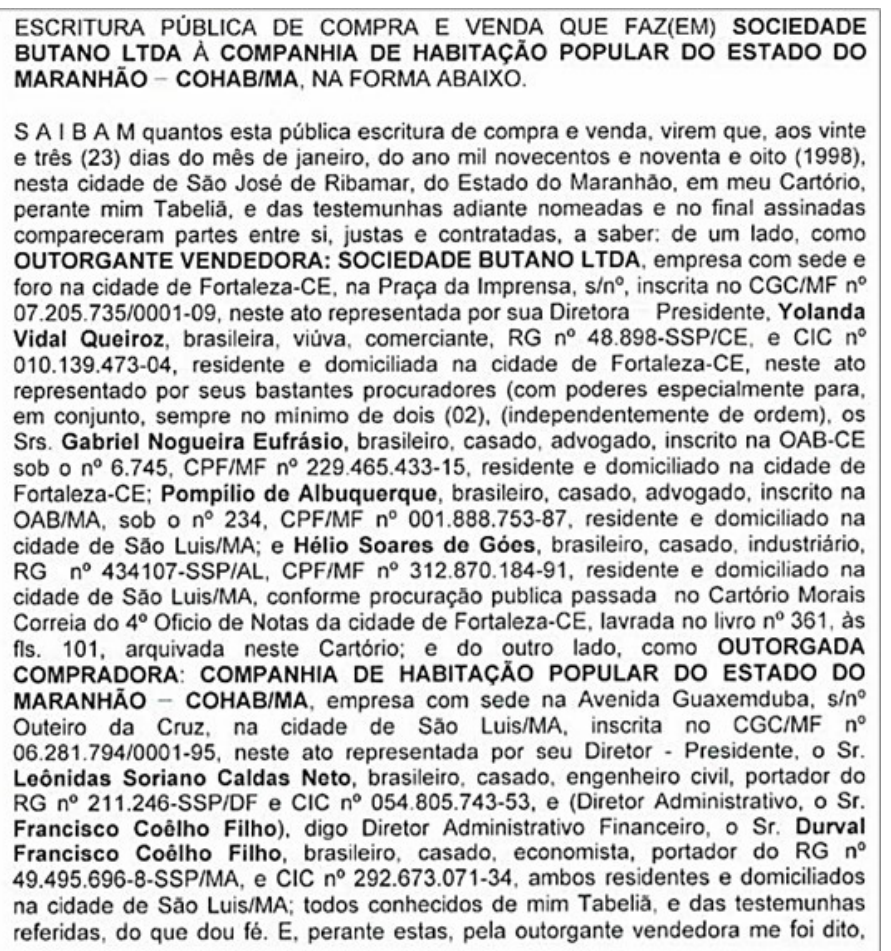

Figura 4. Escritura pública de compra e venda de área para o assentamento de famílias da Cidade Olímpica

Fonte: Fotocópia do livro n 93-A, fl. 96-V a 99, arquivado no $1^{\circ}$ Ofício da Comarca de São José de Ribamar (2019). 
Em relação à propriedade, destaque-se que foi feita uma busca no cartório de São José de Ribamar, a fim de identificar a cadeia sucessória da área de 270,005 hectares adquirida pelo estado do Maranhão, registrado sob matrícula $\mathrm{n}^{0} 32.707$, lavrada no livro $\mathrm{n}^{\circ}$ 93-A, fl. 96-V a 99, constituído de um terreno desmembrado das glebas de terras São Braz e Macacos pertencente à Sociedade Butano Ltda., com registro anterior sob $\mathrm{n}^{\circ}$ 03, matrícula 16.494, fl. 21, livro $\mathrm{n}^{\circ}$ 2-BF. Entretanto, ao solicitar uma certidão de inteiro teor da matrícula $\mathrm{n}^{0}$ 16.494, o autor da pesquisa deparou com um imóvel completamente diferente do descrito na certidão. O registro aponta um terreno com área de $242,37 \mathrm{~m}^{2}$, localizado na área central da cidade de São José de Ribamar, distante cerca de 18 quilômetros da área da Cidade Olímpica.

\section{Regularização fundiária e seus desdobramentos na Cidade Olímpica}

A regularização fundiária consiste em medidas jurídicas, urbanísticas, ambientais e sociais que visam regularizar assentamentos irregulares, e, em decorrência, a cidade, ao conceder propriedade a quem tem direito, ao mesmo tempo que urbaniza as áreas com a instalação de equipamentos públicos que deem suporte à população. Com base nas premissas apontadas pelas legislações federais $\mathrm{n}^{0} 11.977$ (BRASIL, 2009), $\mathrm{n}^{0} 12.424$ (BRASIL, 2011) e $\mathrm{n}^{0} 13.465$ (BRASIL, 2017), bem como pelas legislações estaduais $n^{0} 7.935$ (MARANHÃO, 2003), o Provimento $n^{0}$ 25/2015 da Comissão de Constituição, Justiça e Cidadania (CCJ-MA) (MARANHÃO, 2015a) e o Decreto $n^{0} 30.928$ (MARANHÃO, 2015b), será abordado o processo de regularização fundiária desenvolvido na Cidade Olímpica pelo viés das medidas jurídicas, urbanísticas, ambientais e sociais adotadas na localidade.

\subsection{Primeiro processo de regularização fundiária}

A primeira ação de regularização fundiária no bairro ocorreu no ano de 2003, com a promulgação da Lei $n^{\circ}$ 7.935, de 14 de julho de 2003 (MARANHÃO, 2003), por meio da qual o governo estadual autorizou a doação do imóvel localizado no município de São José de Ribamar, que era de sua propriedade, aos ocupantes já cadastrados da Cidade Olímpica. A lei menciona, em seu artigo $1^{\circ}$, a necessidade de "atender e regularizar o projeto de assentamento de aproximadamente 10.000 (dez mil) famílias ali residentes” (MARANHÃO, 2003). Em 16 de setembro do mesmo ano, a Prefeitura de São José de Ribamar, mediante a Lei n 501 (SÃO JOSÉ DE RIBAMAR, 2003), aprovou o plano de loteamento da Cidade Olímpica. E, em 27 de outubro de 2004, por meio da Lei estadual no 8.179 (MARANHÃO, 2004), foi concedida a isenção de Imposto de Transmissão Causa Mortis e Doação (ITCMD) para os ocupantes do imóvel conhecido como "Cidade Olímpica”, desmembrado das glebas São Braz e Macaco, localizadas em São José de Ribamar. Destaque-se que, nas três leis que tratavam da Cidade Olímpica, o bairro era considerado pertencente ao município 
de São José de Ribamar, e não a São Luís. Convém destacar que, na Lei Municipal $\mathrm{n}^{\circ}$ 3.253, de 29 de dezembro de 1992 (SÃO LUís, 1992), que dispôs sobre o zoneamento, parcelamento, uso e ocupação do solo urbano de São Luís, o bairro estava contido nos limites municipais da capital maranhense como Zona Rural (ZRU). Por conta desse impasse, quanto à definição de o bairro pertencer a um município ou a outro, os quatro mil títulos emitidos para os ocupantes/residentes foram cancelados.

Em consulta ao cartório da $1^{\text {a }}$ Comarca de São José de Ribamar, solicitou-se uma certidão de inteiro teor para confirmar a informação sobre a titulação dos imóveis realizada em 2003. Colhe-se que houve, de fato, a abertura de novas matrículas. Porém, de acordo com informações do tabelião do cartório, a despeito de terem sido abertas novas matrículas, não houve o desmembramento da área nem, consequentemente, sua transferência para o beneficiário.

\subsection{Segundo processo de regularização fundiária}

A segunda tentativa de regularizar a Cidade Olímpica ocorreu em 2013, por intermédio de ações da Secid. Destaque-se que nesse segundo processo de regularização os títulos emitidos foram entregues à população nas datas indicadas na Tabela 1 (SECID, 2013; 2014).

\begin{tabular}{|c|c|c|}
\hline Data da entrega & Quantidade de títulos & Referências \\
\hline $27 / 12 / 2013$ & 590 & Notícia publicada no Imirante.com em $2013^{1}$ \\
\hline $13 / 03 / 2014$ & 153 & Notícia publicada no jornal O Debate do Maranhão em $2014^{2}$ \\
\hline 03/07/2014 & 300 & \\
\hline $22 / 12 / 2014$ & 1.000 & Notícia publicada no Imirante.com em $2014^{3}$ \\
\hline Total & 2.043 & \\
\hline
\end{tabular}

Tabela 1. Datas e números de títulos entregues

Fonte: Secid (2013; 2014).

Ressalte-se que o ano de 2014 foi marcado pelo período eleitoral. Conforme Rolnik (2002, p. 19) aponta, "a distribuição de títulos de terra sem uma melhora significativa nas condições urbanísticas e apenas com objetivos político-eleitorais

\footnotetext{
1. Moradores recebem títulos da regularização fundiária. Imirante.com, São Luís, 28 dez. 2013. Disponível em: https://imirante.com/sao-luis/noticias/2013/12/28/moradores-recebem-titulos-de-regularizacao-fundiaria.shtml. Acesso em: 15 ago. 2020.

2. O debate do Maranhão. Disponível em: http://jornalodebate.com.br/page/2/?s=cidade+ol\%C3\%ADmpica. Acesso em: 15 ago. 2020.

3. Moradores da Cidade Olímpica recebem títulos definitivos. Imirante.com, São Luís, 23 dez. 2014. Disponível em: https:/imirante.com/sao-luis/noticias/2014/12/23/moradores-da-cidade-olimpica-recebem-titulos-definitivos.shtml. Acesso em: 15 ago. 2020.
} 
pode ter efeitos nefastos para a cidade e para a própria população envolvida”. Vale enfatizar que ações de regularidade fundiária não podem ser dissociadas de um conjunto mais amplo de políticas públicas, diretrizes de planejamento e estratégias de gestão urbana. Efetivamente, não houve uma ação conjunta na localidade com serviços de infraestrutura e emissão de títulos. Estes, por sua vez, novamente não tiveram valor jurídico, causando grande decepção para a comunidade.

A busca nos cartórios de São Luís, responsáveis pela emissão do registro (certidão) e da escritura na segunda titulação dos imóveis da Cidade Olímpica, objetivava verificar o teor do documento emitido nos anos de 2013 e 2014, mas não foi possível identificar o motivo para os títulos (certidão e escritura) terem sido invalidados. Afinal, constatou-se que houve o desmembramento da área maior. Na certidão foi indicado que o proprietário, o estado do Maranhão, fez a doação do imóvel e tal ato está lavrado em escritura pública. Ou seja: constam todas as informações necessárias que tornam os documentos legítimos. A única ressalva que se faz é referente ao relato de um dos entrevistados, segundo o qual as escrituras estavam sendo entregues aos ocupantes para estes fazerem o registro no cartório de imóveis. No entanto, com a mudança de governo, na virada de 2014 para 2015, o cartório se recusou a efetuar os registros, em conformidade com acordo estabelecido. Dessa forma, conclui-se que o ato da escritura é legítimo. Entretanto, enquanto a escritura não for registrada, o proprietário, em teoria, continua sendo o estado. Então, para as escrituras emitidas, apenas algumas foram registradas. Informa-se que não foi possível quantificar o número de escrituras cujos registros não foram realizados.

\subsection{Terceiro processo de regularização fundiária}

Partiram da Corregedoria Geral de Justiça do Maranhão (CGJ-MA) as ações para o terceiro processo de regularização fundiária na Cidade Olímpica, em 2015, por iniciativa da juíza Luiza Nepomuceno. O propósito da Corregedoria foi promover a regularização fundiária com base em uma legislação que obrigava município e estado a darem a posse da terra a pessoas que estavam ocupando áreas sem titulação. A instituição, por intermédio da juíza supracitada, buscou apoio do Sinduscon-MA. A regularização fundiária da Cidade Olímpica e de bairros adjacentes teria como arcabouço legal as leis $n^{0}$ 7.935/2003 e $n^{0}$ 8.179/2004, o Provimento $n^{\circ}$ 18/2013 (CGJ/MA) (MARANHÃO, 2013) e a Lei federal n 11.977/2009 (BRASIL, 2009).

A ação foi intitulada Programa de Regularização Fundiária Casa Legal, tendo o apoio da Secid, do Sinduscon-MA, da Federação das Indústrias do Estado do Maranhão (Fiema) e da Amcol. Em virtude das dimensões da área da Cidade Olímpica, cujo cadastro original apontava um total de nove mil unidades habitacionais, foi definido que seria elaborado um projeto piloto para a regularização fundiária. O trabalho seria iniciado com um módulo de quinhentas casas na localidade. 
Com as premissas estabelecidas, foram, então, definidas as etapas do trabalho que precisavam ser realizadas, a saber: relatório, pesquisa de campo, mapeamento, levantamento topográfico, além da aplicação de questionário socioeconômico. Enfatize-se que o Sinduscon-MA esteve envolvido exclusivamente no levantamento cadastral das quinhentas unidades residenciais. E a participação da instituição no processo de regularização fundiária da Cidade Olímpica se deu por via judicial, uma vez que a CCJ-MA a convidou para executar essa ação. Após a entrega do material à Secid, esta se encarregaria de emitir os títulos definitivos de propriedade, em parceria com os cartórios, sob a tutela da CGJ-MA.

Efetivamente, depois do trabalho efetuado pelo Sinduscon-MA em 2016, começaram as primeiras entregas de títulos definitivos de propriedade para as famílias da Cidade Olímpica. Na nova certidão do imóvel constam informações do lote, da edificação, da abertura de nova matrícula, do desmembramento da matrícula-mãe, bem como a respeito da transferência do imóvel em favor dos beneficiários, conforme se vê na Figura 5.

\footnotetext{
AV-01-IVIT:-62.605;PROT:-124.372,PAG.241:- CERTIFICO que, conforme documentos arquivados neste Cartório, amparado pelo Art.213, § 13, da Lel 6.015/73, fica retificado o imóvel da presente matricula, a seguir descrito: Lote de terreno próprio $n^{\circ} 01$, casa 01 , da Quadra 52, Rua 04, Bloco A, Loteamento CIDADE OLIMPICA, nesta cidade de São Luis-MA, com os seguintes dimensões, limites e área:- Inicia a descriçăo deste perímetro do vértice V1. limitando-se com a Casa 25 (Lote 26), com coordenadas N: 9712782.9806 e E: 590410.2463 , deste seguindo com azimute $90^{\circ} 30^{\prime} 58^{\prime \prime}$ e distância de $22,00 \mathrm{~m}$, limitando-se com a Travessa L - chega-se ao vértice V2, de coordenadas N: 9712782.7824 e E: 590432.2454 , deste seguindo com azimute $179^{\circ} 29^{\prime} 2^{\prime \prime}$ e distância de $11,00 \mathrm{~m}$, limitando-se com a Rua 04 - chega-se ao vértice V3, de coordenadas N: 9712772.7829 e E: 590432.1553 , deste seguindo com azimute $270^{\circ} 30^{\prime} 58^{\prime \prime}$ e diståncia de $22,00 \mathrm{~m}$, limitando-se com o Terreno S/N (Lote $02)$ - chega-se ao vértice V4, de coordenadas N: 9712772.9810 e E: 590410.1562 deste seguindo com azimute $359^{\circ} 29^{\prime} 2^{\prime \prime}$ e distância de $11,00 \mathrm{~m}$, limitando-se com as Casas S/N e 25 (Lote 26) - chega-se ao vértice V1 ponto inicial da descriçăo deste perimetro fechando assim esta poligonal definida. Esta poligonal irregular se constitui por 4 (quatro) Vértices $\theta$ Lados, com perímetro de $66,00 \mathrm{~m}$, totalizando uma área de $242,00 \mathrm{~m}^{2}$, com área construída de $120,00 \mathrm{~m}^{2}$, contendo 07 (sete) cômodos, sendo: dois quartos, banheiro, sala, cozinha, copa e terraço. Todas as Coordenadas aqui descritas estão Georeferenciadas ao Sistema Geodésico Brasileiro, representadas no Sistema UTM, referenciadas ao Merldiano Central $45^{\circ} \mathrm{EGr}$, tendo como Datum - SAD-69 todos os azimutes e distâncias, áreas e perimetros eståo calculados no plano de projeçăo UTM. O referido é verdade e dou fé. Sâo Luls/MA, 03 de março de 2017 . Eu $\Theta$ assino afinal em público e raso. Jurandy Leite, Registrador de Imóveis que confiro, subscrevo, dato

R.02,IMat,62.605;Prot.124.372,Pag.241. CERTIFICO que, conforme Lel $n^{\circ} 7.935$, de $14 / 07 / 2013$, assinado pelo governador do Estado do Maranhăo, José Reinaldo Carneiro Tavares; Decreto $n^{\circ} 30.928$, de $10 / 07 / 2015$, alterado pelo Decreto $n^{\circ} 32.459$, de 1/12/2016, ambos assinados pelo Governador do Estado do Maranhăo, Flávio Dino, e ainda conforme Provimento $n^{\circ} 25 / 2015$, da Douta Corregedoria de Justiça do Estado do Maranhăo, assinado pela Desembargadora Nelma Celeste Sarney Costa e com fundamento na Lei $n^{\circ} 11.977 / 2009$, o imóvel objeto desta matricula fica transferido para JOSÉ FRANCISCO BARBOSA MACHADO, brasileiro, casado sob o regime da comunhăo parcial de bens desde 07/12/1999, Cl n000066559496-8 SESP/MA CPF $n^{0} 176.182 .073-72$ e sua esposa MARIA DAS DORES ARAUJO MACHADO, brasileira casada, Cl $\cdot n^{\circ} 016047452000-4$ SESP/MA, CPF $n^{\circ} 471.173 .203-97$, residentes e domiciliados nesta capital, conforme documentos arquivados neste Ćartório. Tendo sido o imóvel avaliado em $\mathrm{R} \$ 12,000,00$, referente à área construida. O referido é verdade e dou fé. Săo Luis/MA, 03 de março de 2017. Eu, Jullalli, Jurandy Leite, Registrador de Imóveis que confiro, subscrevo, dato e assino afinal em público e raso.
}

Figura 5. Título emitido em 2017

Fonte: Cópia do livro n²-F/G, fl. 173 a 241, arquivado no $2^{\circ}$ Ofício de Registro de Imóveis (2017). 


\begin{tabular}{|c|c|c|c|c|}
\hline \multirow{2}{*}{$\mathbf{N}^{\circ}$ da entrega } & \multirow{2}{*}{ Data da entrega } & \multicolumn{3}{|c|}{ Quantidade de títulos entregues por bloco } \\
\hline & & Bloco A & Bloco B & Bloco C \\
\hline $1^{\mathrm{a}}$ & $19 / 01 / 2017$ & 1 & - & 477 \\
\hline $2^{\mathrm{a}}$ & 25/03/2017 & 269 & 1 & 434 \\
\hline $3^{\mathrm{a}}$ & 09/09/2017 & 468 & 528 & 387 \\
\hline $4^{a}$ & $21 / 01 / 2018$ & 172 & 339 & 156 \\
\hline $5^{a}$ & $23 / 06 / 2018$ & 349 & 427 & 199 \\
\hline Pós-entrega 5 & Não informada & 5 & 8 & 5 \\
\hline $6^{a}$ & $14 / 09 / 2019$ & 258 & 255 & 272 \\
\hline Pós-entrega 6 & Não informada & 9 & 3 & 6 \\
\hline $7^{\mathrm{a}}$ & Não informada & - & 3 & 4 \\
\hline Total parcial & & 1.531 & 1.564 & 1.940 \\
\hline Total geral & & & títulos em & \\
\hline
\end{tabular}

Tabela 2. Comparativo entre informações das certidões Fonte: Secid (2019).

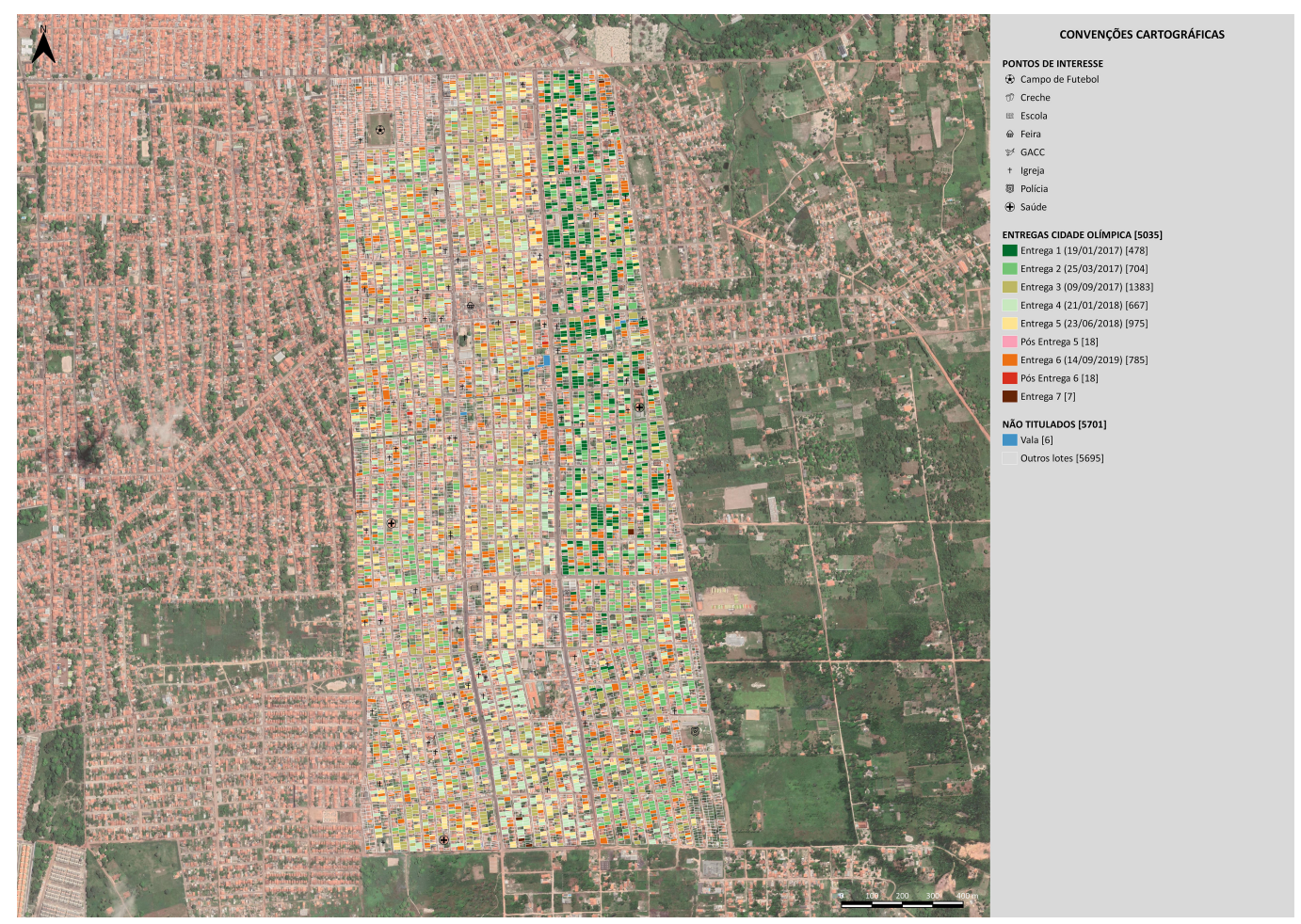

Figura 6. Mapa da Cidade Olímpica com a data das entregas

Nota: *A sigla GACC indica o Grupo de Apoio às Comunidades Carentes do Maranhão.

Fonte: Elaborado pela autora, com base em banco de dados da Secid e em mapa fornecido pelo Sinduscon-MA (2020).

Na Tabela 2, constam a data da entrega dos títulos de propriedade para a população, a quantidade de documentos emitidos por bloco e a data das emissões. Na Figura 6, são apresentados o mapa da Cidade Olímpica e a sinalização dos lotes titulados e dos não titulados, bem como os equipamentos públicos e a quantidade 
de títulos entregues por data. Pode-se notar que os primeiros títulos distribuídos foram para os lotes do Bloco C, cujas quadras foram contempladas com o projeto piloto do Programa de Regularização Fundiária Casa Legal. Na elaboração dos mapas, com os dados disponibilizados pela Secretaria, identificaram-se 5.035 lotes titulados e 5.756 não titulados, totalizando 10.791 lotes. Informa-se que, dos lotes não titulados, 417 se encontram vazios.

\subsection{Percepção quanto ao título de propriedade}

De acordo com Fernandes (2002, p. 16), “os programas de regularização acabam por reproduzir a informalidade urbana em vez de promover a integração socioespacial”. Para esse autor, "a regularização fundiária só é efetivamente demandada pela população quando existe ameaça de expulsão. Passada a ameaça, a demanda maior é por urbanização e por melhores condições de habitabilidade" (FERNANDES, 2002). De fato, a busca pela regularização fundiária da área foi o principal motivo de mobilização da comunidade em seus anos iniciais, demandando muitos anos de ação conjunta da população e da associação de moradores e a articulação desta com os órgãos governamentais responsáveis por regularizá-la. Nesse sentido, as entrevistadas afirmaram que a regularização só aconteceu no bairro em virtude da persistência da comunidade.

Em relação aos questionários aplicados, as pessoas indicaram que, durante o processo de regularização fundiária, foram perceptíveis algumas mudanças no bairro, a saber: (a) a construção de uma escola de Ensino Médio; (b) a construção do batalhão da Polícia; (c) melhoria nas casas (reformas das edificações); (d) pavimentação; (e) iluminação; (f) segurança em relação ao imóvel e possibilidade de venda; (g) valorização do bairro; (h) reforma do posto de saúde. Para $25 \%$ dos entrevistados, as mudanças não foram perceptíveis. Algumas falas são apresentadas a seguir (Quadro 2).

\begin{tabular}{|c|c|}
\hline $\begin{array}{l}N^{\circ} \text { do } \\
\text { questionário }\end{array}$ & Resposta do entrevistado (19/10/2019) \\
\hline 4 & $\begin{array}{l}\text { "Mais uma forma de cidadania. É um documento tipo o título de eleitor que vai te mostrar } \\
\text { que a pessoa é cidadã. Documento muito importante. Antes era a insegurança de a } \\
\text { qualquer momento ter a casa tomada." }\end{array}$ \\
\hline 5 & $\begin{array}{l}\text { "Vai mudar muito. Com o título, a gente pode vender a casa, pode financiar. Sem o título } \\
\text { nada disso podia ser feito." }\end{array}$ \\
\hline 42 & "Uma segurança que agora não é invasão, é meu mesmo." \\
\hline 59 & "Maior segurança; a habitação é a base." \\
\hline 67 & $\begin{array}{l}\text { "O título vai permitir resolver coisas no banco. Morei muito tempo de aluguel e quando } \\
\text { precisava resolver algo no banco eu não conseguia. A segurança é um problema que me } \\
\text { faria sair do bairro." }\end{array}$ \\
\hline 75 & "Gera uma sensação de garantia e estimula a melhora." \\
\hline
\end{tabular}

Quadro 2. Percepção das pessoas quanto ao título de propriedade

Fonte: Elaborado pela autora (2019). 
A titulação sempre foi motivo de muita luta pela população. Todavia, com o passar dos anos e a perspectiva da não retirada ou despejo da área, os anseios da comunidade se tornaram outros. Não há o que questionar sobre a importância da conquista, entretanto, segundo os moradores, a prioridade atual seria o esgotamento sanitário na localidade. Nesse sentido, a resposta ao questionamento "Se vocês tivessem a opção de escolher entre o esgotamento sanitário ou a entrega dos títulos, qual seria a escolha de vocês?” foi:

Resposta: 0 esgotamento sanitário, porque a gente tem que pensar na nossa saúde. $\mathrm{O}$ título de posse vem depois. Eu acho que as pessoas escolheriam o sanitário. Por que as pessoas querem o melhor para o seu bairro, né?!

\section{Considerações finais}

As políticas habitacionais e o mercado formal imobiliário não conseguiram atender à grande demanda por moradia, em razão de se tratar de um produto caro e de alto risco financeiro. De acordo com Maricato (1996), o financiamento habitacional oferecido pelo mercado privado legal não tinha alcance para a população cujos proventos eram menores que dez salários-mínimos. Com isso, a partir dos anos 1980, o número de ocupações de terras urbanas explodiu no Brasil, momento em que o país passava por intenso processo de urbanização e crescimento demográfico: num curto período (1991 a 2005), a população brasileira teve crescimento próximo a 38 milhões de indivíduos (IBGE, 2010).

Dessa forma, as soluções para a moradia foram oferecidas por um mercado clandestino, à revelia dos controles formais do Estado e do mercado. Favelas, invasões ou ocupações e loteamentos irregulares foram a alternativa habitacional e solução possível para milhões de pessoas. Cabe destacar os números levantados pelo IBGE no ano de 2019, em estudo prévio do Censo para coletar informações de saúde para o enfrentamento à Covid-19. Por exemplo, 55,49\% da população de Belém vive em ocupações desordenadas, seguida da de Manaus (53,38\%), Salvador (41,83\%), Vitória (33,16\%) e São Luís, que tem 32,42\% de seus habitantes residindo em aglomerados subnormais.

No entanto, apesar do arcabouço legal existente no que tange à flexibilização do processo de regularização de favelas em áreas irregulares, Fernandes (2007), por exemplo, aponta que somente o reconhecimento de títulos de propriedade não é capaz de promover a integração socioespacial. De fato, apesar de a Cidade Olímpica ter passado por três processos de regularização fundiária entre os anos de $2003 \mathrm{e}$ 2020, tal ação não foi um agente transformador para a comunidade. São inegáveis as conquistas e melhorias na localidade, conforme atesta o relatório produzido em 
2013 pelo governo do estado, referente ao resultado do Índice do Desenvolvimento Humano Municipal (IDHM) das Unidades de Desenvolvimento Humano (UDH) da Região Metropolitana de São Luís, pautado nos indicadores do Programa das Nações Unidas para o Desenvolvimento (PNUD), da Fundação João Pinheiro e do Instituto de Pesquisa Econômica Aplicada (Ipea), em que o bairro com maior crescimento, na comparação dos anos de 2000 a 2010, foi a Cidade Olímpica, cujo índice saltou da classificação de muito baixo desenvolvimento (0,451), em 2000, para a de médio desenvolvimento (0,608), em 2010.

Entretanto, quando se caminha pelo bairro, percebem-se a inexistência de áreas livres e de vegetação e, principalmente, a carência no fornecimento de serviços públicos essenciais, como esgotamento sanitário, drenagem urbana e segurança pública. E esse cenário de precariedade existente na área favorece as condições de insalubridade e violência: desde 2015 o bairro é apontado como o mais violento da Grande São Luís (MARANHÃO, 2017), o que justifica as constantes políticas sociais e intervenções urbanas ali desenvolvidas ao longo dos últimos anos.

Desta forma, conclui-se que a regularização fundiária na Cidade Olímpica foi realizada com a emissão de 5.035 títulos de propriedade, assim divididos: 1.531 no Bloco A, 1.564 no Bloco B e 1.940 no Bloco C, restando, portanto, a titulação de 5.695 lotes. Verificou-se, porém, que nesse processo houve priorização na emissão dos títulos, embora o aspecto jurídico tenha igual relevância no processo de regularização fundiária quando comparado aos aspectos sociais, urbanísticos e ambientais.

Ao avaliar os métodos e critérios adotados na regularização fundiária do bairro, aponta-se que a Secid, o Sinduscon-MA e a CCJ-MA, órgãos envolvidos diretamente no processo, seguiram a metodologia difundida em bibliografia específica sobre o tema, com a realização e a execução do levantamento planialtimétrico cadastral, a selagem dos imóveis, o cadastro socioeconômico e a entrega dos títulos. No entanto, ocorreu apenas a coleta de dados - que não se transformou em informação. Ressalte-se que a produção de informações, principalmente num trabalho dessa magnitude, é essencial para delinear estratégias para reforçar a política pública de regularização fundiária em curso no estado do Maranhão. Os dados coletados pela Secid são apenas números, isto é, são fatos não processados. Com isso, a Secretaria não consegue extrair um significado detalhado do trabalho de regularização fundiária da Cidade Olímpica, por não ter sistematizado os dados, e tampouco permite que outros o façam, pois somente a informação é capaz de dar sentido ao que com efeito foi analisado.

Quanto ao arcabouço legal que subsidiou o Programa de Regularização Fundiária no bairro, em virtude de o processo de titulação ter se iniciado em 2003, os títulos basearam-se tanto nas diretrizes previstas no Estatuto da Cidade como na lei relativa ao Programa Minha Casa Minha Vida (PMCMV) e, mais recentemente, na 
Lei federal da Regularização Fundiária Urbana (Reurb) (BRASIL, 2017). Como ponto inicial sobressai a aquisição da área pelo governo estadual em janeiro de 1998, fato que permitiu a promulgação da Lei estadual $n^{0} 7.935$ (MARANHÃO, 2003), autorizando a doação da área da Cidade Olímpica para os ocupantes com vistas a regularizar o projeto de assentamento. Em seguida, temos a publicação do Provimento $n^{\circ}$ 25/2015 (MARANHÃO, 2015a) e o Decreto estadual n 30.928 (MARANHÃO, 2015b), que instituiu o Programa de Demarcação Urbanística, com o objetivo de regularizar áreas do estado, constituídas de assentamentos irregulares urbanos ocupados predominantemente por população de baixa renda. O decreto teve fundamentação jurídica nos artigos 46 a 68 da Lei federal nº 11.977/2009 (BRASIL, 2009). Destaquese ainda a Medida Provisória $n^{\circ} 295$ (MARANHÃO, 2019), que instituiu o Programa de Regularização Fundiária Urbana no Estado do Maranhão (Reurb), baseado nos termos da Lei federal $n^{0}$ 13.465/2017 (BRASIL, 2017).

No que concerne aos aspectos urbanísticos, sociais, jurídicos e ambientais, conforme dados coletados na aplicação dos questionários e nas entrevistas, os ganhos são significativos. Em termos urbanísticos, houve a construção de equipamentos públicos, como escolas e posto de saúde, além da instalação de um batalhão da Polícia Militar, a pavimentação de ruas, especialmente no Bloco C, e a disponibilização de iluminação pública em todas as vias. Quanto aos aspectos sociais, os moradores apontaram a melhoria nas casas (esta de responsabilidade dos proprietários), situação que indica uma melhora na renda para investir na reforma dos imóveis. No tocante à questão jurídica, os títulos representam a segurança em relação ao imóvel, com possibilidade de venda. Já no que se refere aos aspectos ambientais, há necessidade de promover avanços, sobretudo no tratamento do esgoto, na drenagem urbana e na recuperação do canal Santo Antônio.

Conclui-se que a ausência de um plano macro de regularização fundiária permitiu ações isoladas de políticas públicas, em muitos casos, desencontradas, causando o retrabalho de alguns processos e desconfiança de parte da população, submetida a três processos de regularização fundiária. Portanto, esta pesquisa não encerra a discussão sobre o assunto, mas pode subsidiar o debate sobre os processos de regularização fundiária e seus efeitos nas comunidades, pois, de acordo com Fernandes (2011), são raros os relatórios sistemáticos com resultados dos projetos de regularização fundiária na América Latina.

Finaliza-se este texto com o apontamento de Albuquerque (2020) sobre a forma de regularizar assentamentos informais no país, apontada por ele como um quadro de "enxugar gelo". Ressalte-se que não houve exposição de opinião anteriormente, mas se trata de uma reflexão que talvez possa gerar discussões para uma próxima pesquisa. Esse autor comenta que é necessária uma mudança crucial na forma de regularizar os assentamentos informais no Brasil, com a transferência 
dessa incumbência da regularização para a iniciativa privada, mediante a criação de mecanismos para que a própria comunidade forneça uma solução para a falta de infraestrutura, uma vez que o poder público não vai dar conta de resolver o problema de todos os assentamentos informais, tendo em vista sua dimensão.

\section{Referências}

ALBUQUERQUE, A. Regularização fundiária. São Paulo: Caos Planejado, 12 mar. 2020. Podcast. Disponível em: https://caosplanejado.com/?s=andr\% $\mathrm{C}_{3} \% \mathrm{~A} 9+$ albuquerque. Acesso em: 14 ago. 2020.

ALFONSIN, B. D. M. O significado do Estatuto da Cidade para os processos de regularização fundiária no Brasil. In: ROLNIK, R. et al. Regularização fundiária sustentável: conceitos e diretrizes. Brasília, DF: Ministério das Cidades, 2007. p. 68-99.

ARANTES, P. F. Da (anti) reforma urbana brasileira a um novo ciclo de lutas nas cidades. Carta Maior, Rio de Janeiro, 12 nov. 2013. Disponível em: https://www.cartamaior.com. br/?/Editoria/Cidades/Da-Anti-Reforma-Urbana-brasileira-a-um-novo-ciclo-de-lutasnas-cidades-/38/29523. Acesso em: 14 ago. 2020.

BOSCO, F. O que é um lar. Revista CULT, 20 fev. 2017. Disponível em: https://revistacult.uol. com.br/home/francisco-bosco-o-que-e-um-lar/. Acesso em: 7 ago. 2020.

BRASIL. Lei $\mathrm{n}^{0}$ 12.424, de 16 de junho de 2001. Altera a Lei $\mathrm{n}^{0}$ 11.977, de 7 de julho de 2009, que dispõe sobre o Programa Minha Casa, Minha Vida - PMCMV e a regularização fundiária de assentamentos localizados em áreas urbanas, as Leis nos 10.188, de 12 de fevereiro de 2001, 6.015, de 31 de dezembro de 1973, 6.766, de 19 de dezembro de 1979, 4.591, de 16 de dezembro de 1964, 8.212, de 24 de julho de 1991, e 10.406, de 10 de janeiro de 2002 - Código Civil; revoga dispositivos da Medida Provisória nº 2.197-43, de 24 de agosto de 2001; e dá outras providências. Diário Oficial da União: Brasília, DF, 17 jun. 2011, rep. 20 jun. 2011.

Lei $\mathrm{n}^{0}$ 11.977, de 7 de julho de 2009. Dispõe sobre o Programa Minha Casa, Minha Vida - PMCMV e a regularização fundiária de assentamentos localizados em áreas urbanas; altera o Decreto-Lei no 3.365, de 21 de junho de 1941, as Leis nos 4.380, de 21 de agosto de 1964, 6.015, de 31 de dezembro de 1973, 8.036, de 11 de maio de 1990, e 10.257, de 10 de julho de 2001, e a Medida Provisória no 2.197-43, de 24 de agosto de 2001; e dá outras providências. Diário Oficial da União: Brasília, DF, 8 jul. 2009.

. Lei $n^{0} 13.465$, de 11 de julho de 2017. Dispõe sobre a regularização fundiária rural e urbana, sobre a liquidação de créditos concedidos aos assentados da reforma agrária e sobre a regularização fundiária no âmbito da Amazônia Legal; institui mecanismos para aprimorar a eficiência dos procedimentos de alienação de imóveis da União; altera as Leis nos 8.629, de 25 de fevereiro de 1993, 13.001, de 20 de junho de 2014, 11.952, de 25 de junho de 2009, 13.340, de 28 de setembro de 2016, 8.666, de 21 de junho de 1993, 6.015, de 31 de dezembro de 1973, 12.512, de 14 de outubro de 2011, 10.406, de 10 de janeiro de 2002 (Código Civil), 13.105, de 16 de março de 2015 (Código de Processo Civil), 11.977, de 7 de julho de 2009, 9.514, de 20 de novembro de 1997, 11.124, de 16 de junho de 2005, 6.766, de 19 de dezembro de 1979, 10.257, de 10 de julho de 2001, 12.651, de 25 de maio de 2012, 
13.240, de 30 de dezembro de 2015, 9.636, de 15 de maio de 1998, 8.036, de 11 de maio de 1990, 13.139, de 26 de junho de 2015, 11.483, de 31 de maio de 2007, e a 12.712, de 30 de agosto de 2012, a Medida Provisória ${ }^{\circ} 2.220$, de 4 de setembro de 2001, e os Decretos-Leis ${ }^{\circ}$ 2.398, de 21 de dezembro de 1987, 1.876, de 15 de julho de 1981, 9.760, de 5 de setembro de 1946, e 3.365, de 21 de junho de 1941; revoga dispositivos da Lei Complementar $\mathrm{n}^{0} 76$, de 6 de julho de 1993, e da Lei ${ }^{\circ}$ 13.347, de 10 de outubro de 2016; e dá outras providências. Diário Oficial da União: Brasília, DF: 8 set. 2017.

BRASIL. Relatório de gestão. Brasília, DF: Ministério do Desenvolvimento Regional, 2019.

BURNETT, F. L. São Luís por um triz: escritos urbanos e regionais. São Luís: Uema, 2011.

CARDOSO, A. L. Irregularidade urbanística: questionando algumas hipóteses. Cadernos Metrópole, Rio de Janeiro, n. 10, p. 9-25, $2^{\text {o }}$ sem. 2003.

Avanços e desafios na experiência brasileira de urbanização de favelas. Cadernos Metrópole, São Paulo, p. 219-240, $1^{\circ}$ sem. 2007. Disponível em: http://www. urbanismo.mppr.mp.br/arquivos/File/CARDOSO_Avancosedesafiosnaxperiencia brasileiradeurbanizacaoeavelas.pdf. Acesso em: 25 ago. 2020.

Assentamentos precários no Brasil: discutindo conceitos. In: IPEA. Caracterização e tipologia de assentamentos precários: estudos de caso brasileiros. Brasília, DF: Ipea, 2016. p. 29-52.

DAVIS, M. Planeta Favela. São Paulo: Boitempo, 2006.

FACCHINI, N. M. O direito à moradia x o direito de propriedade. Conteúdo Jurídico, 10 out. 2014. Disponível em: http://www.conteudojuridico.com.br/consulta/Artigos/41158/odireito-a-moradia-x-o-direito-de-propriedade. Acesso em: 2 nov. 2019.

FAJERSZTAJN, L.; VERAS, M.; SALDIVA, P. H. N. Como as cidades podem favorecer ou dificultar a promoção da saúde de seus moradores? Estudos Avançados, São Paulo, v. 30, n. 86, p. 7-27, 2016.

FERNANDES, E. Os programas de regularização. In: ALFONSIN, B. et al. Regularização da terra e da moradia: o que é e como implementar. São Paulo: Instituto Pólis, 2002. p. 15-16.

Regularização de assentamentos informais: o grande desafio dos municípios, da sociedade e dos juristas brasileiros. In: ROLNIK, R. et al. Regularização fundiária sustentável: conceitos e diretrizes. Brasília, DF: Ministério das Cidades, 2007. p. 18-33.

. Regularização de assentamentos informais na América Latina. São Paulo: Lincoln Institute of Land Policy - Foco em Políticas Fundiárias, 2011.

FIEMA. Federação das Indústrias do Estado do Maranhão. Moradores da Cidade Olímpica são beneficiados com programa de regularização fundiária. São Luís: Ascom: Sinduscon, 2015.

G1-MA. São Luís é a 5 a capital brasileira com maior percentual de habitação em aglomerados. 19 maio 2020. G1-MA, 19 maio 2020. Disponível em: https://g1.globo.com/ma/maranhao/ noticia/2020/05/19/sao-luis-e-a-5a-capital-brasileira-com-maior-percentual-de-habitacao-em-aglomerados.ghtml. Acesso em: 5 ago. 2020. 
GONÇALVES, R. S. Repensar a regularização fundiária como política de integração socioespacial. Estudos Avançados, São Paulo, v. 23, n. 66, p. 237-250, 2009.

GONÇALVES, R. S.; BAUTÈS, N.; MANEIRO, M. A informalidade urbana em questão. O Social em Questão, Rio de Janeiro, ano XXI, n. 42, p. 9-26. set.-dez. 2018.

HARVEY, D. O trabalho, o capital e o conflito de classes em torno do ambiente construído nas sociedades capitalistas avançadas. Espaço e Debates: temas urbanos e regionais, São Paulo, p. 6-35, 1982.

IBGE. Instituto Brasileiro de Geografia e Estatística. Documentação do Censo 20oo. Rio de Janeiro: IBGE, 2002.

. Censo demográfico 2010. Rio de Janeiro: IBGE, 2010.

. Acesso à internet e à televisão e posse de telefone móvel celular para uso pessoal: 2015. Rio de Janeiro: IBGE, 2016.

Aglomerados subnormais 2019: Classificação preliminar e informações de saúde para o enfrentamento à COVID-19. Nota técnica 01/2020. Rio de Janeiro: IBGE, 2020.

LOPES, J. A. V. São Luís. Ilha do Maranhão e Alcântara: guia de arquitetura e paisagem. Sao Luís; Sevilla: Ministério da Cultura, 2008.

MARANHÃO. Lei nº 7.935, de 14 de julho de 2003. Autoriza o Poder Executivo a doar o imóvel de sua propriedade que especifica, e dá outras providências. Diário Oficial do Estado do Maranhão: São Luís, 4 ago. 2003. Disponível em: http://legislacao.al.ma.gov.br/ged/ busca.html;jsessionid=e3zQNVFFeC5nZ5yWkcvYoKlWPMyJoP_F3Qcuwsu7.intranet. Acesso em: 15 ago. 2020.

. Lei $\mathrm{n}^{\circ}$ 8.179, de 27 de outubro de 2004. Concede isenção de Imposto de Transmissão causa mortis e doação, e dá outras providências. Diário Oficial do Estado do Maranhão: São Luís, 5 nov. 2004. Disponível em: https://sistemas1.sefaz.ma.gov.br/portalsefaz/pdf?codigo=576. Acesso em: 15 ago. 2020.

. Corregedoria Geral de Justiça. Provimento nº 18/2013. [Dispõe sobre o procedimento de regularização imobiliária e fundiária.]. Diário Oficial do Estado do Maranhão: Poder Judiciário, São Luís, 20 nov. 2013.

. Corregedoria Geral de Justiça. Provimento nº 25/2015. [Dispõe sobre o procedimento de regularização imobiliária e fundiária.]. Diário Oficial do Estado do Maranhão: Poder Judiciário, São Luís, ed. 118, 3 jul. 2015 a.

. Decreto $\mathrm{n}^{\circ}$ 30.928, de 10 de julho de 2015. Institui o Programa de Demarcação Urbanística para a regularização fundiária de áreas do Estado do Maranhão, declaradas de interesse social, constituídas de assentamentos irregulares ocupados, predominantemente, por população de baixa renda, em área urbana e para fins de moradia. Diário Oficial do Estado do Maranhão: São Luís, 2015b.

. Manual prático da Reurb. São Luís: Secid, 2016.

. Ministério Público do Estado. Relatório quantitativo de criminalidade na Grande Ilha de São Luís: $1^{0}$ semestre de 2017. São Luís: MPMA, 2017. p. 76.

Medida Provisória $\mathrm{n}^{\circ}$ 295, de 26 de junho de 2019. Institui o Programa de Regularização Fundiária Urbana no Estado do Maranhão (REURB-MA) e o Fundo 
Estadual Imobiliário - FEI, dispõe sobre a Empresa Maranhense de Administração de Recursos Humanos e Negócios Públicos - EMARHP e altera a Lei no 10.521, de 19 de outubro de 2016, e a Lei ${ }^{\circ} 11.000$, de 02 de abril de 2019. Diário Oficial do Estado do Maranhão: São Luís, 26 jun. 2019.

MARICATO, E. Metrópole na periferia do capitalismo: ilegalidade, desigualdade e violência. São Paulo: Hucitec, 1996.

. A terra é um nó na sociedade brasileira... também nas cidades. Cultura Vozes, v. 93, n. 6, p. 7-22, nov.-dez. 1999.

MATEUS, C. G.Direito àmoradia x direito à propriedade. Campo Grande: Sedep, 2005. Disponível em: https://www.sedep.com.br/artigos/direito-a-moradia-x-direito-a-propriedade/\#: : text=\%E2\%80\%93\%20A\%20moradia\%2odiferencia\%2Dse\%2oda,vezes\%2C\%2odispens $\% \mathrm{C}_{3} \%$ A1vel\%2C\%20isto\%20\%C3\%A9\%2C. Acesso em: 2 nov. 2019.

ONU. Organização das Nações Unidas. ONU prevê que cidades abriguem 70\% da população mundial até 2050. ONU News, 2019a. Disponível em: https://news.un.org/pt/ story/2019/02/1660701. Acesso em: 7 ago. 2020.

Organização das Nações Unidas. World population prospects 2019. New York: United Nations, 201gb.

PADILHA, L. L. Propriedade e moradia, direitos que se opõem na realidade brasileira (parte 2). JusBrasil, 2017. Disponível em: https:/leopadilha95.jusbrasil.com.br/artigos/489209626/ propriedade-e-moradia-direitos-que-se-opoem-na-realidade-brasileira-parte-2. Acesso em: 2 nov. 2019.

RABÊLO, R. D. L. Direito à cidade capitalista: da luta popular pela terra ao impasse no acesso à propriedade e aos serviços públicos na Cidade Olímpica em São Luís-MA. 2012. Dissertação (Mestrado em Desenvolvimento Socioespacial e Regional) - Universidade Estadual do Maranhão, São Luís, 2012.

RIBEIRO JÚNIOR, J. R. B. Formação do espaço urbano de São Luís: 1612-1991. 2. ed. São Luís: Ed. do autor, 2001.

ROLNIK, R. A dimensão política da irregularidade e da regularização. In: FERNANDES, E. Regularização da terra e da moradia: o que é e como implementar. São Paulo: Instituto Pólis, 2002.

. et al. Regularização fundiária sustentável: conceitos e diretrizes. Brasília, DF: Ministério das Cidades, 2007. 304 p.

. Guerra dos lugares: a colonização da terra e da moradia na era das finanças. São Paulo: Boitempo, 2015.

SANTO, J. M. E. São Luís: uma leitura da cidade. São Luís: Instituto da Cidade, 2006.

SANTOS, C. N. F. D. A desordem é só uma ordem que exige uma leitura mais atenta. Revista de Administração Municipal - Municípios - Ibaim, Rio de Janeiro, ano 54, n. 271, p. 8-13, jul.-set. 2009.

SÃO JOSÉ DE RIBAMAR. Lei $\mathrm{n}^{0}$ 501, de 16 de setembro de 2003. Autoriza a aprovação do Loteamento Cidade Olímpica. Diário Oficial do Município de São José de Ribamar: São 
José de Ribamar, 16 set. 2003. Disponível em: https://www.saojosederibamar.ma.gov.br/ legislacao. Acesso em: 15 ago. 2020.

SÃO LUÍS. Lei n ${ }^{0}$ 3.253, de 29 de dezembro de 1992. Dispõe sobre a instituição do Plano Diretor do município de São Luís, e dá outras providências. Diário Oficial do Município de São Luís: ano XIII, no 8, 15 abr. 1993. Disponível em: https://www.saoluis.ma.gov.br/midias/ anexos/1188_3-lei_n._3.253_de_29.12.1992_d.o.m._n.88._pags._06-27.pdf. Acesso em: 15 ago. 2020.

. Relatório de análise retrospectiva (1993-2012) e cenários de São Luís (2013-2033) e do seu contexto regional. São Luís: Macroplan: Prefeitura de São Luís, 2013.

SOARES, F. S. A. Cidade Olímpica: a memória da luta pela terra urbana. Monografia (Graduação em Geografia) - Universidade Estadual do Maranhão, São Luís, 2008.

SOTO, H. D. O mistério do capital: por que o capitalismo dá certo nos países desenvolvidos e fracassa no resto do mundo. Rio de Janeiro: Record, 2001. 


\section{Ângela Maria Pinheiro da Silva}

Arquiteta e urbanista pela Universidade Estadual do Maranhão (Uema, 2007). Mestra pelo Programa de Pós-graduação em Geografia, Natureza e Dinâmica do Espaço - Linha de Pesquisa: Dinâmicas Socioterritoriais, Modernizações e Desigualdades, pela mesma instituição (2020). Atualmente, atua como consultora na área de arquitetura no projeto de reassentamento das famílias de Mariana e Barra Longa, em Minas Gerais, afetadas pelo rompimento da barragem de Fundão.

Email: angela_arquitetura@hotmail.com

ORCID: 0000-0003-4885-5190

Contribuição de autoria: conceituação, investigação/pesquisa, metodologia e escrita - primeira redação.

\section{Cláudio Eduardo de Castro}

Doutor em Geografia pela Universidade Estadual Paulista (Unesp), campus de Presidente Prudente. É professor nos cursos de licenciatura e bacharelado em Geografia e de pósgraduação em Geografia, Natureza e Dinâmica do Espaço da Universidade Estadual do Maranhão (Uema), campus São Luís, onde trabalha com o território em suas relações sociedade-natureza. Bolsista de Produtividade Uema.

Email: clanaros@yahoo.com.br

ORCID: 0000-0002-1224-5019

Contribuição de autoria: orientação de pesquisa, conceituação, metodologia.

Submissão: 5 de abril de 2021.

Aprovação: 6 de outubro de 2021.

Como citar: SILVA, A. M. P. da; CASTRO, C. E. Direito de propriedade: análise da política pública fundiária na Cidade Olímpica, em São Luís (MA). Revista brasileira de estudos urbanos e regionais. v. 23, E2O2142, 2021. DOI 10.22296/2317-1529.rbeur.202142

Artigo licenciado sob Licença Creative Commons CC BY 4.0.

https://creativecommons.org/licenses/by/4.o/deed.pt_BR 